\title{
JOSIP JURAJ STROSSMAYER U HRVATSKOJ POLITICI*
}

\author{
- POLITIKA I NACIONALNA IDEOLOGIJA
}

\begin{abstract}
Biskup Josip Juraj Strossmayer vodeća je osoba Narodne stranke i najistaknutija osoba u političkom životu Hrvatske u drugoj polovici 19. stoljeća. Strossmayer i Narodna stranka pripadnici su tradicionalne društvene elite, sljednici hrvatskog preporodnog pokreta prve polovice 19. stoljeća i pokreta 1848. godine. Prikazan je sustav Strossmayerove nacionalne integracijske ideologije: hrvatska, slavenska i južnoslavenska ideja te političko djelovanje s ciljem ostvarenja samostalnosti Hrvatske u sklopu Monarhije i ostvarenja uloge Hrvatske u rješenju istočnog pitanja, napose položaja Bosne.

Ključne riječi: Josip Juraj Strossmayer; Hrvatska; Habsburška Monarhija; Hrvati; Srbi; južni Slaveni; književni jezik; istočno pitanje; Osmansko Carstvo; Bosna.
\end{abstract}

Biskup Josip Juraj Strossmayer (1815. - 1905.), biskup srijemski i bosanski sa sjedištem u Đakovu, bio je najistaknutija osoba hrvatskoga političkog i javnog života u drugoj polovici 19. stoljeća, prisutan svojom političkom djelatnosti i izvan Hrvatske - u Habsburškoj Monarhiji te na zapadnoeuropskom prostoru i na prostoru jugoistočne Europe.

O njegovoj političkoj i kulturnoj djelatnosti objelodanjena su brojna znanstvena djela, posvećeni su mu i zbornici radova sa znanstvenih skupova održanih u Akademiji. ${ }^{1}$ U zborniku sa skupa održanog 2005., posvećenog 100. obljetnici Strossmayerove smrti i 190. obljetnici rođenja, tiskan je i članak autora ovog priloga o Strossmayerovu političkom djelovanju u sklopu političkih kretanja u

* Članak je nastao na osnovi izlaganja na znanstvenom skupu o 150. obl,jetnici rođenja Josipa Jurja Strossmayera održanog u Hrvatskoj akademiji znanosti i umjetnosti 2015. godine.

1 Usp. zadnja dva Akademijina zbornika posvećena Strossmayeru tiskana 1997. i 2005.: Zbornik radova o Josipu Jurju Strossmayeru (glavni ur. Ivo PADOVAN, ur. Dobriša SKOK), Zagreb: HAZU, 1997; Međunarodni znanstveni skup Josip Juraj Strossmayer povodom 190. obljetnice rođenja i 100. obljetnice smrti Zagreb, 19. svibnja 2005. (ur. Franjo ŠANJEK), Zagreb: HAZU, 2006. Usp. također zbornik međunarodnog skupa održanog u organiziaciji Jagiellonskog sveučilišta u Krakowu 2005.: Josip Juraj Strossmayer. Hrvatska. Ekumenizam., Europa / Chorwacja. Ekumenizm. Europa (ur. Maria DABROWSKA-PARTYKA, Maciej CZERWINSKI), Krakow: Wydawnictvo Sekunda, 2007. 
Srednjoj Europi i samoj Habsburškoj Monarhiji nakon revolucije 1848. te nakon ukidanja Bachova apsolutizma i obnove političkog života u Monarhiji i Hrvatskoj 1860. godine. ${ }^{2} \mathrm{U}$ ovom izlaganju pažnja je posvećena njegovu političkom djelovanju u njegovu društvenom i ideologijskom kontekstu.

Strossmayer je preporodno doba prve polovice 19. stoljeća proveo dijelom na studiju u Pešti i zatim u Beču na Augustineumu, zavodu za više obrazovanje svećenika, zatim kao profesor na sjemeništu u Đakovu. Od 1847. godine bio je u Beču jedan od trojice ravnatelja Augustineuma i dvorski kapelan. Već za studija u Pešti u pretpreporodno i rano preporodno doba upoznao je učenje Slovaka Jana Kollára o slavenskoj uzajamnosti i južnim Slavenima kao jednoj od četiri velike slavenske skupine. Pratio je preporodna kretanja u Hrvatskoj, ali nije u njima izravno sudjelovao. Za revolucije 1848./49. godine povezao se s krugom slavenskih i hrvatskih političara koji su dolazili u Beč, pa i s banom Josipom Jelačićem, kojemu je zatim prenosio povjerljive poruke dvora. Godine 1849. predavao je kanonsko pravo na Sveučilištu, na Bogoslovnom fakultetu, i nudila mu se sveučilišna karijera, također mjesto ministerijalnog savjetnika u Ministarstvu prosvjete, ali se opredijelio za stolicu đakovačkog biskupa na koju je postavljen zagovorom bana Jelačića i pristankom „apostolskog“ cara Franje Josipa. ${ }^{3}$ Desetgodišnji Bachov apsolutizam uklonio je političke rezultate pokreta 1848. godine, a Strossmayer se kao biskup posvetio crkvenom životu i unapređivanju biskupijskog vlastelinstva, jednog od najvećih zemljišnih posjeda u Hrvatskoj koji mu je omogućio da živi grandseigneurski, ali i da financijskom potporom kulturnoj i znanstvenoj djelatnosti postane najveći donator i, uz skromna Vladina financijska sredstva, svojevrsni izvaninstitucionalni ministar kulture i znanosti.

U javni politički život Strossmayer je stupio nakon ukidanja Bachova apsolutizma 1860. godine i obnove političkog života u Habsburškoj Monarhiji te je u Hrvatskoj postao čelna osoba vodeće Narodne stranke. To će ostati tijekom sljedećeg nešto više od jednog desetljeća, do sklapanja tzv. revizije Hrvatsko-ugarske nagodbe 1873. godine, nakon čega se povukao iz javnog političkog života, ali je i nakon toga iz pozadine utjecao na politička kretanja. ${ }^{4}$

$\overline{2}$ Nikša STANČIĆ, Josip Juraj Strossmayer u kontekstu hrvatske i europske politike, u: Međunarodni znanstveni skup Josip Juraj Strossmayer, n. dj.,35-50. Usp. također: isti, Strossmayerovo i Starčevićevo doba hrvatske politike, u: Zbornik radova 6. Strossmayerovih dana, Đakovo, 2008., 9-46.

3 Tade SMIČIKLAS, Nacrt života i djela biskupa J. J. Strossmayera, I. Izabrani njegovi spisi: govori, rasprave i okružnice, Zagreb: JAZU, 1906., 2-8; Hodimir SIROTKOVIĆ, Život i djelo đakovačkog biskupa Josipa Jurja Srossmayera, u: Međunarodni znanstveni skup Josip Juraj Strossmayer, n. dj. 25-26, STANČIĆ, Nikša, Die Idee der "slawischen Wechselseitigkeit" von Ján Kollár und ihre kroatische Rezeption, u: Ján Kollár a slovanská vzájomnost'. Genéza nacionalizmu v strednej Európe, Bratislava: Stimulus, 2006., 174-185.

4 Cjeloviti prikaz Strossmayerova život i djelovanja v. kod: William BROOKS TOMLJANOVICH, Biskup Strossmayer: nacionalizam i moderni katolicizam u Hrvatskoj, Zagreb: Hrvatska akademija znanosti 
Strossmayer i Narodna stranka bili su sljednici preporodne Narodne stranke i hrvatskog pokreta 1848. godine, i to po socijalnom mentalitetu kao predstavnici društvenog sloja koji se $\mathrm{u}$ društvenim znanostima naziva tradicionalnom društvenom elitom, po modelu nacionalne ideologije i po političkom programu.

1.

U hrvatskom preporodnom pokretu i pokretu 1848. godine sudjelovao je sloj tradicionalne društvene elite, sloj koji je u hrvatskom, društveno duboko polariziranom društvu bio sastavljen od građanstva oblikovnog u feudalnom društvu i plemstva te svjetovne i svećeničke inteligencije plemićkog i građanskog porijekla. Tako je pokret 1848. godine u skladu sa svojim socijalnim sastavom svoj liberalni građanski program društvenih reforma proveo u varijanti konzervativnog liberalizma, ukidajući staleže i kmetstvo, ali ne dirajući u gospodarsku snagu napose visokog plemstva. Seljaku je, ukidajući saborskim zaključcima kmetstvo, ostavio zemlju koju je dotad u sklopu vlastelinstva obrađivao za sebe i iz koje su proizlazile njegove obveze prema vlastelinu, dok je plemstvu ostavio alodijalnu zemlju koju je dotad obrađivao uz pomoć kmetske radne snage. ${ }^{5}$ A izbornim redom pravo na sudjelovanje u saborskim izborima bilo je visokim imovinskim i obrazovanim cenzusom ograničeno na tek nekoliko postotaka stanovništva (dakako, muškaraca) uz očuvanu instituciju virilista, tj. prava pripadnika aristokracije, dužnosnika i visokog svećenstva da u Sabor dolaze na banski poziv, bez sudjelovanja na izborima. ${ }^{6}$ Po takvom izbornom redu provedeni su i izbori za Sabor 1861. godine, te je i Strossmayer u njegovu radu sudjelovao kao banski uzvanik, a ni kasniji izborni zakoni nisu znatnije mijenjali njegova načela. ${ }^{7}$

Modernizacijske reforme provođene $\mathrm{u}$ vrijeme Bachova apsolutizma intervencijama iz Beča i zatim domaćim snagama nakon 1860. uklanjale su feudalne

i umjetnosti - Dom i svijet, 2001. O Strossmayerovu kulturnom i političkom djelovanju usklađenom s kompleksom njegove nacionalne ideologije v. kod: Leopold AUBURGER, Grundzüge der Kulturpolitik von Josip Juraj Strossmayer / Kroatien als Kulturzentrum und als Kulturvermittler im südslavischen Raum, Zeitschrift für Balkanologie, 48, 2012., 22-48.

5 Članak XXVII. O ukinutju urbara i urbarskih službah, u: Hrvatski državni sabor 1848., sv.I. (ur. Josip KOLANOVIĆ, prir. Iskra IVELJIĆ, Josip KOLANOVIĆ, Nikša STANČIĆ), Zagreb: Hrvatski državni arhiv, 2001., 571-572.

6 Naredba o pozivanju i zastupanju Sabora Kraljevinah Dalmacie, Hèrvatske i Slavonie imajućem se dèržat dana 5. i sliedećih mieseca lipnja t. g. u Zagrebu, napravljena u vieću banskom dana 8. i sliedećih mieseca svibnja 1848., u: Hrvatski državni sabor 1848., n.dj., 225-229.

7 Hodimir SIROTKOVIĆ, Izborni red za Sabor od 1861. godine i provođenje izbora, Rad JAZU 347, 1967., 211-276; Dalibnor ČEPULO, Izborna reforma u Hrvatskoj 1875. - liberalizam - antidemokratizam i hrvatska autonomija, Zbornik Pravnog fakulteta u Zagrebu, 52, 2002. (3-4), 665-692. 
institucije i uvodile institucije građanskog društva u upravi, sudstvu, školstvu, ali se, uz spori gospodarski napredak, vrlo sporo mijenjala i struktura društva. Strossmayer i nositelji političke akcije nakon 1860. bili su, kao i prije njih, nositelji preporodnih kretanja, pripadnici tradicionalne društvene elite tek dijelom izmijenjene društvenim promjenama nakon 1848. godine. Građanski sloj ostao je i dalje skroman, a njegov uspon ograničavali su kako centralistički tako dualistički režim koji su gospodarski razvoj Hrvatske podvrgavali interesima bečkog, odnosno budimpeštanskog središta. Skromno će ojačati do 1880-ih godina i ući u politički život pod ideologijom Stranke prava, koja će od Narodne stranke preuzeti vodeću ulogu u političkom životu, dok je nije potisnuo režim bana KhuenHéderváryja. ${ }^{8}$

U vrijeme Strossmayerova djelovanja bilo je tijekom 1860 -ih godina u sjevernoj Hrvatskoj nepismeno oko $85 \%$ stanovnika na selu i oko $50 \%$ u gradovima, a još 1880 . godine oko $85 \%$ stanovnika živjelo je na selu i tek oko $15 \%$ u gradovima. ${ }^{9}$ Selo je bilo gospodarski stagnantno i neobrazovano te nedostupno političkoj agitaciji. Ono je, dakle, u vrijeme prevlasti na političkoj sceni Strossmayerove Narodne stranke sa svojom hrvatskom etničkom svijesti živjelo izvan političke sfere spontano rabeći hrvatsko ime za sebe i jezik kojim govori. Međutim to njegovo etničko hrvatstvo nije bilo politički operabilno. Selo će se gospodarski i socijalno, pa i obrazovno, dinamizirati tek krajem 19. stoljeća, a politički počet će ga organizirati seljački pokret braće Radić na početku 20. stoljeća, u vrijeme kada se počeo oblikovati novi sustav političkih odnosa u Hrvatskoj. Ima simbolike u činjenici da je Hrvatska pučka seljačka stranka osnovana potkraj 1904., četiri mjeseca prije, a Riječka rezolucija donesena u drugoj polovici 1905., pola godine poslije Strossmayerove smrti u travnju 1905.

\section{2.}

Struktura Strossmayerove nacionalne ideologije u osnovi je slijedila strukturu preporodne ideologije. Bitne sastavnice Strossmayerove nacionalne ideologije bile su hrvatska, slavenska i južnoslavenska ideja, pojmovi unutar sebe kompleksni i međusobno na različite načine povezani. To su bile sastavnice preporodne i poslijepreporodne ideologije pod kojom je provođen proces hrvatske nacionalne integracije tradicionalnih društvenih elita. Te su elite svoj nacionalni

\footnotetext{
8 Igor KARAMAN, Hrvatska na pragu modernizacije (1750-1918), Zagreb: Naklada Ljevak, 2000., 192272.

9 Mirjana GROSS, Agneza SZABO, Prema hrvatskome građanskom društvu / Društveni razvoj u civilnoj Hrvatskoj i Slavoniji šezdesetih $i$ sedamdesetih godina 19. stoljeća, Zagreb: Globus nakladni zavod, 1992., $35,37$.
} 
identitet uz osjećaj etničke pripadnosti zasnivale na intelektualnoj razini nadovezujući se na kulturu prethodnog, predmodernog razdoblja koja je svoj protonacionalni identitet temeljila na jeziku i na državnopravnoj tradiciji povijesnih "trojednih kraljevina“ Hrvatske, Slavonije i Dalmacije.

U Strossmayerovoj nacionalnoj ideologiji i političkim koncepcijama središnje mjesto zauzimao je etnički i politički kroatizam. ${ }^{10}$ Hrvatski etnos za nj je samorazumljiva kategorija, također Hrvatska koja kao aktualno Kraljevstvo Dalmacije, Hrvatske i Slavonije nosi neprekinuti državnopravni kontinuitet od samostalne srednjovjekovne Hrvatske.

Trojni naziv „Hrvatska, Slavonija i Dalmacija“ bio je u oficijelnoj uporabi u Strossmayerovo doba sve do 1918. godine, ali je napredak hrvatskog protonacionalnog i zatim nacionalnog integracijskog procesa dolazio do izražaja u fenomenu koji autor ovih redaka naziva izlaskom iz plurala, naime $u$ postupnoj zamjeni trojnog naziva nazivom „Hrvatska“. ${ }^{11}$ Prvi put to su u službenoj uporabi učinili hrvatski nunciji u Ugarskom saboru 1790. godine, kad su svoju predstavku u vezi s pokušajem uvođenja mađarskog kao službenog jezika umjesto latinskog u naslovu nazvali izjavom nuncija Kraljevstva Hrvatske (Regni Croatiae), a u bilješci objasnili da pod tim imenom razumiju Kraljevstva Dalmacije, Hrvatske i Slavonije (Regna Dalmatiae, Croatiae et Slavoniae). ${ }^{12}$

Strossmayer je u političkim nastupima rabio "trojedni“ naziv i ime „Hrvatska“. Ime „Hrvati“ rabio je u etničkom smislu kad je naprimjer uspoređivao osobine Čeha i Hrvata, ${ }^{13}$ ali je ime "Hrvati“ rabio također u političkom smislu označavajući time "politički narod“, političke i socijalne nositelje suverenosti Hrvatske, odnosno povijesne tvorce i u suvremenosti socijalne i političke nositelje njezina povijesnog državnog prava. $U$ tome je postupao prema zapadnom modelu političkog nacionalizma u građanskim državama koje su od predmodernog društva naslijedile državne institucije i prilagodile ih modernom društvu i u kojima su građani nosili nacionalno ime po državi, neovisno o svojoj očuvanoj etničkoj individualnosti. ${ }^{14}$ I Hrvatska je, kao i Ugarska (za razliku od naprimjer Slovenaca i Slovaka), naslijedila političke institucije predmodernog

\footnotetext{
$\overline{10}$ Nikša STANČIĆ, Hrvatska nacija i nacionalizam u 19. i 20. stoljeću, Zagreb: Barbat, 2002. Usp. poglavlje „Osvit nacije. Građanski nacionalizam i etnonacionalizam", str. 3-68.

11 STANČIĆ, Hrvatska nacija i nacionalizam, n.dj., 141-143. Usp. poglavlje: „Izlazak iz plurala i izlazak iz genitiva".

12 Declaratio ex parte nunciorum regni Croatiae quoad inducendam Hungaricam linguam, kod: Franjo FANCEV, Dokumenti za naše podrijetlo Hrvatskoga preporoda (1790-1832), Zagreb: JAZU, 1933. 33-37. Usp. u putopisu iz 1875.: Josip Juraj Strossmayer, Putopisne crtice, u: SMIČIKLAS, Nacrt života i djela biskupa J. J. Strossmayera, n. dj. 325, 329.

14 STANČIĆ, Hrvatska nacija i nacionalizam, 21-25.
} 
društva - bana, sabor, upravni sustav - koje su nakon 1848. godine prilagođene građanskom društvu, što je bila osnovica za oblikovanje elemenata političkog nacionalizma. Strossmayerov govor, koji je 1861. godine održao u Saboru iznoseći podatke o načinu na koji je Hrvatska regulirala državnopravne odnose s Ugarskom u prošlosti i prijedloge o njihovu uređenju nakon ukidanja Bachova apsolutizma, vrvi izrazima „Hrvati“ i "mi Hrvati“ u političkom smislu. Tako su, prema njegovim riječima, „Hrvati“ prihvatili savez s Ugarskom (Pacta conventa 1102.), „Hrvati“ su samostalno izabrali Habsburgovce za hrvatske kraljeve (sabor u Cetinu 1527.) i priznali njihovo nasljedstvo u ženskoj lozi (hrvatska Pragmatička sankcija 1712.). ${ }^{15}$

Strossmayer je na političkoj razini, osjećajući se Hrvatom u etničkom i političkom smislu, s mnogo entuzijazma nastupao zahtijevajući obnovu povijesne samostalnosti i teritorijalne cjelovitosti Hrvatske u Habsburškoj Monarhiji. Rješenje političkog položaja Hrvatske vidio je u sklopu rješenja političkih odnosa u Srednjoj Europi i (o čemu niže) u jugoistočnoj Europi. Zahtijevajući samostalni položaj Hrvatske u Habsburškoj Monarhiji, pozivao se na spomenute suverene odluke "Hrvata“ (tj. Hrvatskog sabora) o ulasku u državnu zajednicu s Ugarskom i zatim neovisno o Ugarskoj o prihvaćanju dinastije Habsburgovaca, pri čemu, ako je nakon toga Hrvatska pod vanjskim pritiskom i gubila znatne elemente samostalnosti, njezino državno pravo nije ugasnulo. ${ }^{16} \mathrm{U}$ konkretnoj političkoj situaciji nakon ukidanja apsolutizma 1860. - nadovezujući se na zaključke Hrvatskog sabora 1848. godine o raskidu državnopravnih veza s Ugarskom - zahtijevao je priznanje neovisnosti Hrvatske o Ugarskoj, obnovu teritorijalne cjelovitosti Hrvatske priključenjem sjevernoj Hrvatskoj Dalmacije i s vremenom Vojne krajine te federalizaciju Habsburške Monarhije, pri čemu bi ujedinjena Hrvatska bila jedna od federalnih jedinica. To je Sabor 1861. i prihvatio kao zakonski članak 42., koji je vladar potvrdio. ${ }^{17}$

U političkoj akciji Strossmayer i Sabor s narodnjačkom većinom nastojali su regulirati položaj Hrvatske vodeći računa o odnosima u Monarhiji i položaju Habsburške Monarhije u Srednjoj Europi. Istodobno su željeli osigurati suradnju

15 Strossmayerov govor u Saboru 1861. O državnopravnim odnosima između Hrvatske i Ugarske, kod: Josip Juraj STROSSMAYER, Izabrani književni i politički spisi I.. (prir. Dubravko JELČIĆ) Zagreb: Matica hrvatska, 2005., 106-133. Izraz „mi Hrvati“ Strossmayer je samo je na jednoj stranici (115) upotrijebio tri puta.

16 Usp. nav. Strossmayerov govor u Saboru 1861. O državnopravnim odnosima između Hrvatske i Ugarske.

Članak 42. O odnošenju trojedne kraljevine Dalmacije, Hrvatske i Slavonije prema kruni i kraljevini Ugarskoj, kod: Tihomir CIPEK, Stjepan MATKOVIĆ, Programatski dokumenti hrvatskih političkih stranaka i skupina 1842.-1914., Zagreb: Disput, 2006., 139-140. 
s Ugarskom u zajedničkom otporu bečkom centralizmu. Strossmayer i Sabor 1861. godine odbili su zahtjev Beča da Hrvatska pošalje zastupnike u Carevinsko vijeće, središnji parlament za centralistički uređenu Monarhiju, jer bi se time promijenio državnopravni položaj Hrvatske, koja državnopravno nije bila dio zapadnog dijela Monarhije, time ni dio povijesnog Njemačko-Rimskog Carstva, odnosno aktualnog postnapoleonskog Njemačkog saveza kojemu su pripadale i austrijske zemlje. Strossmayer je smatrao da bi izravnim ulaskom u Carevinsko vijeće Hrvatska promijenila svoj državnopravni okvir i državnopravno postala dio zapadnog dijela Monarhije. Time bi se Hrvatska u konkretnim političkim prilikama, u vrijeme kad su Beč i Berlin bili pretendenti na vodeću ulogu u stvaranju velike Njemačke u okvirima povijesnog Njemačko-Rimskog Carstva - kad bi svenjemačko ujedinjenje provela Pruska ili Austrija - našla u državi s njemačkom hegemonijom. Zbog toga je bio spreman prihvatiti tek da Hrvatska bude preko predstavnika imenovanih u Saboru prisutna u središnjim upravnim tijelima koja bi odlučivala o krugu poslova zajedničkih za čitavu Monarhiju: vojsku, vanjsku politiku i financije za zajedničke poslove. ${ }^{18}$

S druge su strane, zbog zajedničkog otpora bečkom centralizmu i opasnosti od njemačke hegemonije, Strossmayer i Narodna stranka bili spremni prihvatiti obnovu državnopravnih veza s Ugarskom raskinutih 1848., ali uz uvjet da Ugarski sabor prethodno prizna neovisnost Hrvatske, tj. da se veze uspostave na ravnopravnoj osnovi i uz dogovor o zajedničkim poslovima. Nasuprot tome, dio članova Narodne stranke bio je spreman glasovati u Saboru za odluku da Hrvatska pošalje zastupnike u Carevinsko vijeće bez prethodnih uvjeta. Oni su uz podršku Ivana Mažuranića, tada predsjednika Hrvatske dvorske kancelarije u Beču, osnovali Samostalnu narodnu stranku, ali je ona na izborima 1865. godine doživjela poraz. ${ }^{19} \mathrm{~S}$ druge strane, mađarska je politika $\mathrm{u}$ to vrijeme, uoči izbijanja rata između Austrije i Pruske, već pokazivala spremnost na nagodbu s dvorom i nije bila spremna obnovu odnosa s Hrvatskom prihvatiti uz prethodno priznanje samostalnosti Hrvatske, te su pregovori Strossmayera na čelu saborskog kraljevinskog odbora s mađarskom stranom 1866. godine bili bezuspješni. ${ }^{20}$ Nakon poraza austrijske vojske u bitci kod Sadove ljeti 1866. bio

\footnotetext{
18 Usp. nav. Strossmayerov govor u Saboru 1861. O državnopravnim odnosima između Hrvatske i Ugarske.

19 Nikša STANČIĆ, Ivan Mažuranić Ivan Mažuranić i projekt austro-hrvatske nagodbe, Hrvatska revija 14, 2014., br. 4., 56-58; Nikša STANČIĆ, Ivan Mažuranić kao političar - između želja i mogućnosti, Mažuranićev zbornik, Zagreb: HAZU, 2015., 19-21.

20 Usp. Strossmayerov govor O nagodbi između Hrvatske i Ugarske. Govor kao predsjednika Hrvatskoga kraljevinskog odbora u Pešti , 16. lipnja 1866., kod; STROSSMAYER, Izabrani književni i politički spisi, n. dj., 163-177.
} 
je otvoren put kompromisu Beča i Budimpešte. Strossmayer se u travnju 1867., $\mathrm{u}$ vrijeme pripremanja Austro-ugarske nagodbe, $\mathrm{u}$ audijenciji kod cara Franje Josipa I. - koju je potom opisao u pismu Franji Račkom - odlučno suprotstavio uvođenju dualizma i nagodbi Hrvatske s Ugarskom prije nego što Ugarska prizna samostalni položaj Hrvatske, na što mu je vladar zaprijetio „prisilnim mjerama" (Zwangsmassregeln) ako u Saboru ne podrži nagodbu. Strossmayer je na to otputovao u Pariz. ${ }^{21}$ Beč i mađarska politika Austro-ugarskom nagodbom 1867. podijelili su vlast nad ostalim, najvećim dijelom slavenskim narodima Monarhije. A Hrvatska se našla u sklopu ugarskog dijela Monarhije, prepuštena da se sama nagodi s mađarskom politikom.

Hrvatski sabor s unionističkom većinom, izabran pod pritiskom vlasti, prihvatio je 1868. godine Hrvatsko-ugarsku nagodbu, prema kojoj je Hrvatskoj ostavljena tek skromna autonomija u sklopu zemalja ugarske krune. A prihvaćanje Nagodbe u Saboru bio je poraz Strossmayerove politike. Strossmayer i Narodna stranka vjerovali su ipak da dualizam, tj. njemačka i mađarska prevlast u većinski slavenskoj Monarhiji, ne može biti trajno rješenje. No, nakon ujedinjenja Njemačke i proglašenja Njemačkog Carstva 1871. kancelar Bismarck odustao je od projekta velike Njemačke, prihvatio opstanak cjelovite Habsburške Monarhije i podržao dualizam te time vladajući položaj Nijemaca u suradnji s Mađarima u Monarhiji, čime je dualizam postao trajna činjenica. ${ }^{22}$

Narodna je stranka u novim uvjetima odustala od otpora dualizmu i prihvatila oportunističku politiku, a pod pritiskom je u svoje redove primila umjerene unioniste. Strossmayer je 1872. godine prihvatio članstvo u saborskoj deputaciji za razgovore o reviziji Nagodbe, ali uz uvjet da se u pregovorima zatraži promjena položaja Hrvatske. Zahtijevao je imenovanje bana bez potpisa mađarskog predsjednika vlade, vladu odgovornu Saboru, financijsku samostalnost, zastupljenost Rijeke u Hrvatskom saboru, upravno prilagođavanje Vojne krajine za sjedinjenje s Provincijalom i sjedinjenje Dalmacije sa sjevernom Hrvatskom ili bar izgradnju željezničkog spoja s Dalmacijom. ${ }^{23}$ No, tijekom pregovora vođenih u Budimpešti uvidio je da su članovi hrvatske deputacije spremni prihvatiti neizmijenjenu Nagodbu, što će 1873. i Sabor prihvatiti, te je odlučio povući se ne samo iz deputacije već i iz javnog političkog djelovanja. Tu je svoju odluku

\footnotetext{
21 Opis audijencije kod Franje Josipa v. u pismu: Strossmayer - Račkom,, Beč 29. travnja 1867., u: Korespondencija Rački - Strossmayer (ur. Ferdo ŠIŠIĆ) I., Zagreb: JAZU, 1923 ., 45 (dalje: KORS).

22

O nastanku i sadržaju Hrvatsko-ugarske nagodbe v.: Vasilije KRESTIĆ, Hrvatsko-ugarska nagodba 1868., Beograd: Srpska akademija nauka i umetnosti, 1969.; Josip ŠARINIĆ, Nagodbena Hrvatska I Postanak i osnove ustavne organizacije, Zagreb: Nakladni zavod Matice hrvatske, 1972. ssmayer - Račkom, Rogatec, 19. srpnja 1872, kod: KORS I., 187, 188.
} 
u pismu Franji Račkom u listopadu 1872. najavio riječima: „Odsele pako nikad više politike ne ću tjerati u skupu s našimi ljudmi, nego ako živ budem i ako to korist zemlje zahtijevala bude, sam. ${ }^{24}$ Tako je nakon prihvaćanja tzv. revizije Nagodbe u Saboru 1873. i postupio, te se od tada povremeno iz pozadine politički angažirao, kao što je to učinio naprimjer u vezi s istočnom krizom otvorenom ustankom u Bosni i Hercegovini 1875. - 1878. ili u vezi s osnivanjem 1880. i djelovanjem oporbene Neodvisne narodne stranke, odnosno 1894. godine s njezinim koaliranjem sa Strankom prava, koja je odstupila od radikalnog Starčevićeva programa.

3.

Prema shvaćanju Strossmayera i Narodne stranke, pripadnost Hrvata slavenskom i unutar toga užem, južnoslavenskom jezičnom korpusu bila je okvirna odrednica hrvatskog etničkog identiteta i u tome su oni također bili sljednici ideologije preporodnog pokreta. Isticanje pripadnosti Hrvata slavenskoj cjelini bilo je istodobno u konkretnim političkim prilikama sredstvo kojim je uspostavljan diferencijalni razmak prema vladajućim neslavenskim nacijama - njemačkoj, mađarskoj i talijanskoj - u Habsburškoj Monarhiji i na hrvatskom prostoru.

I Strossmayerov ekumenizam, ideja o približavanju katoličke i pravoslavnih crkava, imao je istodobno vjersku i političku funkciju. Kao crkveni katolički dostojanstvenik Strossmayer je težio obnovi jedinstva Kristove crkve i isticao je upravnu, ali ne i dogmatsku odvojenost katolicizma i pravoslavlja. „Ja sam Rim sklonio - pisao je Račkom 1883. god. - da prizna, da među nami i njima (tj. između katolika i pravoslavnih; N.S.) nema dogmatičke diferencije." Uporabu staroslavenskog jezika u liturgiji smatrao je sredstvom „da se jezikom u misi jedni drugima približimo“. Dapače, produžio je u pismu, „samo od okolnosti zavisi, da ja Rimu ne kažem, da se on sam crkvi istočnoj toliko približiti ima, koliko i ona njemu“. ${ }^{25}$ Put prema približavanju slavenskih katoličkih i pravoslavnih naroda vidio je u sklapanju konkordata između Crne Gore $\mathrm{u}$ čemu je uspio) te Srbije i napose Rusije sa Svetom Stolicom. God. 1876. uputio je tajni memorandum ruskoj vladi predlažući joj sklapanje konkordata s Rimom te smatrajući da bi to uklonilo nepovjerenje europskih naroda prema Rusiji i otvorilo put prema ukidanju germanske (njemačke) ili romanske (francuske) prevlasti u Europi i omogućilo da Rusija postane treći, ravnopravni čimbenik u politici na europskom kontinentu, što bi - u skladu s nakanama Promisli - otvorilo razdo-

\footnotetext{
24 Strossmayer - Račkom, Budimpešta, 25. listopada 1872. KORS, I , 190. 
blje suradnje i mira. ${ }^{26}$ To bi, dakako, i ostale slavenske narode izvelo na svjetsku pozornicu. U telegramu poslanom rektoru Kijevskog sveučilišta 1888. godine u povodu 900. obljetnice pokrštenja Rusa Strossmayer je u istom smislu poručio: „Bog blagoslovio Rusiju i dao joj da [...] i onu veličajnu svesvjetsku zadaću, koju joj Promisao božja opredijeli, sretno, spasonosno i slavodobitno ispuni.“ To je bio povod za oštru reakciju cara Franje Josipa za njegova susreta sa Strossmayerom na primanju tijekom boravka na manevrima u Bjelovaru. ${ }^{27}$

Strossmayer i Narodna stranka smatrali su jezik bitnim obilježjem nacionalnog identiteta, tj. prihvaćali su (uz politički kroatizam) srednjoeuropski model etnonacionalizma, poimanje o jeziku kao obilježju nacionalnog identiteta. ${ }^{28}$ Zbog toga je Strossmayerova nacionalna ideologija sadržavala i shvaćanje o južnim Slavenima - Slovencima, Hrvatima, Srbima i Bugarima - kao etničkoj zajednici zasnovanoj na jezičnoj bliskosti. Nazivao ih je različitim oblikom zajedničkog imena: „Slaveni na jugu“, kojima je namijenio i ,jugoslavensko sveučilište u Zagrebu ${ }^{\prime 29}$, ",narod jugoslavjanski ${ }^{\prime / 30}$ i sl. Pritom je Hrvate i Srbe smatrao dvjema zasebnim etnijama, ali - zbog zajedničkog jezika - istodobno dionicima zajedničkog hrvatskog i srpskog identiteta u sklopu južnoslavenske jezične i etničke cjeline, odnosno „hrvatsko-srpskim narodom ${ }^{\prime \prime}{ }^{31}$ A takvo je poimanje preporodnog pokreta i zatim Strossmayera i Narodne stranke bilo posljedica načina na koji su se u 19. stoljeću - drugačije nego u prethodnom razdoblju - oblikovali hrvatski i srpski standardni jezici, odnosno njihova susreta ili sudara u 19. stoljeću.

Proces standardizacije hrvatskoga književnog jezika - o čemu je ovdje riječ tek u naznakama - tekao je od renesanse, pri čemu je u tom procesu bila trajno prisutna tendencija približavanja triju hrvatskih narječja. ${ }^{32}$ Taj jezik u procesu standardizacije nazivan je slovinskim, ilirskim i hrvatskim, ili su ilirsko i hrvat-

$\overline{26}$ Josip Juraj Strossmayer, Memorandum ruskoj vladi 1876., kod: STROSSMAYER, Izabrani književni i politički spisi, n.dj., 271-289.

Tekst telegrama Strossmayer je prenio u pismu Račkom, Rogatec, 27. srpnja 1888., a opis razgovora s Franjom Josipom I. u pismu iz Križevaca 13. rujna 1888, , KORS IV., Zagreb, 1931., 5 i 21-22.

STANČIĆ, Hrvatska nacija i nacionalizam, n.dj., 141-143. Usp. odjeljak „Srednjoeuropske nacije i nacionalizmi", 31-62.

29 V. govor u Saboru 1861.: Josip Juraj STROSSMAYER, O potrebi osnivanja akademije znanosti i sveučilišta, kod: STROSSMAYER, Izabrani književni i politički spisi, n.dj., 100.

30 Strossmayer - Račkom, Đakovo, 28. siječnja 1868., KORS I., 56.

31 Naziv "hrvatsko-srpski narod“ Strossmayer je upotrijebio na pr. u zahvali Akademiji na čestitci koju mu je uputila u povodu 50-godišnjice misništva - v. prilog uz pismo Račkom, Đakovo, 24. veljače 1888, KORS III., 354. 
sko ime za jezik i narod rabljeni kao sinonimi. ${ }^{33}$ Tako su naprimjer u nekim istaknutim slučajevima istodobno, sredinom 18. stoljeća, postupali na hrvatskom jugu i sjeveru autori književnih i leksikografskih djela Filip Grabovac i Andrija Jambrešić. Štokavac Grabovac svoj je spjev nazvao Cvit razgovora jezika i naroda iliričkoga aliti arvackoga (1747.), ${ }^{34}$ a kajkavac Jambrešić u svojem je latinsko-,„ilirsko“njemačkom rječniku „ilirsko“-latinski prilog, s početnim hrvatskim riječima, naslovio Index illyrico seu croatico latinus (1742.). ${ }^{35}$

Prosvijećeni je apsolutizam u skladu s intencijama upravne unifikacije težio jezičnoj i grafijskoj standardizaciji, ali postojećih književnih idioma, ne i stvaranju jedinstvenoga hrvatskoga standardnog jezika i grafije, pa su tako naprimjer od kraja 18. stoljeća nastajali zasebni školski udžbenici za „horvatsko“ i za „slavonsko pravopisanje ${ }^{\prime 36}$ Naprotiv, u prvim desetljećima 19. stoljeća istaknuti su pojedinci, koji su u historiografiji označeni kao „preteče“ preporoda, iskazivali intencije prema postupnoj izgradnji jedinstvenoga hrvatskog standardnog jezika povezivanjem elementa štokavštine, kajkavštine i čakavštine. Tako je naprimjer 1818. godine Juraj Matija Šporer namjeravao u Beču pokrenuti novine pod naslovom Oglasnik ilirski jezikom koji bi bio spoj svih hrvatskih narječja. U pozivu na pretplatu isticao je da će jezik novina biti „hervatskom, slavonskom, dalmatinskom i istrianskom izgovoru tako priređen, da od svakog bolje zemući, uvik pred oči imao bude svakome po moći razumjen se učinit“. ${ }^{37}$ Time je bio zacrtan samostalan put izgradnje hrvatskoga standardnog jezika.

Istodobno su u drugoj polovici 18. i na početku 19. stoljeća kod Srba u Ugarskoj i Hrvatskoj (Vojvodini i Vojnoj krajini) bila, uz crkveni ruskoslavenski, u književnosti u uporabi dva jezika. U javnom životu, školstvu i upravnoj praksi, pa i u književnosti namijenjenoj "graždanstvu“, bio je u uporabi slavenosrpski jezik, nestabilna mješavina narodne štokavštine i elemenata crkvenoslavenskog i ruskog jezika u gramatici, sintaksi i u vokabularu za pojmove koji su prelazili razinu agrarnog društva. Središta kulturne djelatnosti bila su u Novom Sadu te u Pešti i Beču, gdje su djelovale srpske kolonije i gdje su djelovali nakladnici te

\footnotetext{
33 Diana STOLAC, Nazivi hrvatskoga jezika od prvih zapisa do danas, Filologija, 27., 1996.,107-121.

34 Usp. pretisak: Filip GRABOVAC, Cvit razgovora jezika i naroda iliričkoga aliti arvackoga, Zagreb: Školska knjiga, 2007.

35 Andrija JAMBREŠIĆ, Lexicon latinum interpretatione illyrica, germanica et hungarica, Zagreb, 1742., pretisak Zagreb: Zavod za hrvatski jezik Hrvatskoga filološkog instituta, 1992., v. prilog: „Index illyrico seu croatico latinus", str. [1069].

36 Napuchenye vu horvatzko pravopiszanye, z-pravochtenyem y glaszomerenyem, za potrebnozt narodnih skol Vugerzkoga y Horvatzkoga Orszaga, Budim 1780.; Uputjenje k'slavonskomu pravopisanju za potrebu narodnieh ucsionicah u Kraljevstvu Slavonie, Budim, 1779. 
izlazile su novine na takvom književnom jeziku u procesu standardizacije. Štokavska djela hrvatskih pisaca, poput Relkovićeva Satira, da bi postala prihvatljiva obrazovanim Srbima, prevođena su na slavenosrpski. U literaturi namijenjenoj puku bila je u uporabi narodna štokavština, a od kraja 18. stoljeća djelovali su pojedinci poput Dositeja Obradovića koji su smatrali da jezik književnosti treba temeljiti na narodnom govoru. Objektivno su i oni u praksi u svojm jeziku očuvali elemente slavenosrpskog jezika. ${ }^{38}$

Izneseni podatci pokazuju da su do početka 19. stoljeća usporedno tekli procesi oblikovanja dvaju standardnih jezika, hrvatskog i srpskog.

Promjene u oblikovanju srpskoga standardnog jezika počele su nastupati od početka 19. stoljeća vanjskom intervencijom, Karadžićevom reformom srpskoga književnog jezika koja je nastala kao projekt Slovenca Jerneja Kopitara. Kopitar, kustos u Kraljevskoj knjižnici u Beču, i cenzor slavenskih knjiga te suradnik austrijskog redarstva, smatrao je sve štokavce, katolike i pravoslavne, Srbima (a hrvatske kajkavce Slovencima). Želio je, u skladu s austrijskom politikom, pravoslavne Srbe odvojiti od ruskog utjecaja, a jedno od sredstava za ostvarenje tog cilja vidio je u njihovu napuštanju srpskoslavenskoga književnog jezika i polaganju osnovice srpskoga književnog jezika na narodnu štokavštinu i time njihovu približavanju štokavcima, po njegovu shvaćanju katoličkim Srbima. Smatrao je da Srbi moraju izgraditi standardni jezik na narodnoj štokavštini, ali i jeziku književnosti i leksikografskih djela Hrvata štokavaca. Nadarenog suradnika za realizaciju toga svog projekta našao je u Vuku Stefanoviću Karadžiću, izbjeglici iz Srbije nakon poraza srpskog ustanka, kojega je upoznao u Beču 1813. godine. Karadžića je opskrbio rječnicima hrvatskih autora koji su u 18. i na početku 19. stoljeća nastali u procesu standardizacije hrvatskoga jezika (Joakim Stulli, Ardelio Dela Bella, Josip Voltić, Jakov Mikalja, Andrija Jambrešič, Ivan Belostenac). Karadžićevim djelovanjem položeni su na početku 19. stoljeća temelji za izgradnju srpskoga standardnog jezika na narodnoj štokavštini uz korištenje terminologije civilizacijske razine iz rječničkog korpusa nastalog u sklopu procesa oblikovanju hrvatskoga standardnog jezika. ${ }^{39}$ Karadžićev Srpski rječnik tiskan je u hrvatsko pretpreporodno doba, 1818. godine, kada je Strossmayer imao tri godine. Iste godine Matija Šporer objavio je poziv na pretplatu za Oglasnik ilirski, koji je namjeravao izdavati na tipu jezika u skladu s dotadašnjim tijekom u procesu izgradnje hrvatskoga standardnog jezika.

\footnotetext{
38 Milorad PAVIĆ, Istorija srpske književnosti klasicizma i predromantizma / Klasicizam, Beograd: Nolit, 1979., 119-191; KATIČIĆ, Hrvatski jezik, n.dj., 193,194.

39 Mario GRČEVIĆ,"Jernej Kopitar kao strateg Karadžićeve književnojezične reforme, Filologija ,53, 2009., Zagreb, 1 -53.
} 
Hrvatsko preporodno doba pripada završnoj etapi oblikovanja hrvatskoga standardnog jezika. Prijelomni trenutak zbio se kada su Gajeve Novine, preporodno glasilo, 1836. godine počele izlaziti na štokavštini. Osnovica jedinstvenoga hrvatskog standardnog jezika time je bila položena na knjiženu štokavštinu, ali - u skladu s dotad zacrtanim načelima - uz uključivanje elemenata ostalih hrvatskih narječja. Bliskost Karadžićeve isključivo štokavske osnovice novoga srpskog standardnog jezika omogućavala je nastanak (netočne) predodžbe o jedinstvenom hrvatskom i srpskom standardnom jeziku. Preporod je za taj jezik istaknuo ilirsko ime koje je ostalo u javnoj uporabi do njegove zabrane 1843. godine. Tako se tek od sredine 19. stoljeća počinje uz hrvatski rabiti višečlani naziv za jezik - hrvatski i srpski, hrvatski ili srpski, hrvatsko-srpski i sl. s različitim početnim nacionalnim imenom. ${ }^{40}$ Ta je predodžba bila prisutna i u poslijepreporodnom razdoblju, a prihvaćali su je i Strossmayer i Rački. ${ }^{41}$

Sam Strossmayer oduševljeno je prihvatio drugo izdanje Karadžićeva Srpskog rječnika iz 1849. godine i na početku svojega biskupovanja 1851. otkupio je od Karadžića dvadeset primjeraka izdanja te u okružnici preporučio svećenicima svoje biskupije da izdanje nabave u njegovoj dijecezanskoj pisarnici. ${ }^{42} \mathrm{Da}$ pače, zajedno s predsjednikom Akademije Franjom Račkim uredio je da Đuro Daničić s beogradske Visoke škole prijeđe u Zagreb i preuzme mjesto Akademijina tajnika te zadatak izrade kapitalnog djela, Rječnika hrvatskoga ili srpskoga jezika, temeljenog na Karadžićevim načelima, tj. načelima hrvatskih „vukovaca“. To je Strossmayeru bio dokaz već spomenutog shvaćanja o bliskoj etničkoj srodnosti, premda ne i identičnosti Hrvata i Srba kao dijela šire etničke cjeline koju je označavao jugoslavenskim imenom, pa je i Akademija, kojoj je pridavao misiju europeizacije čitavoga tog prostora, nosila ime „Jugoslavenska akademija znanosti i umjetnosti“.

Neki autori koji su postavljali temelje suvremenim metodama u historiografiji ocjenjivali su ,jugoslavizam“ Strossmayera i Narodne stranke kao „hrvatsku nacionalnu integracijsku ideologiju. ${ }^{\prime 43}$ Ovdje treba napomenuti, u skladu sa samim njihovim metodološkim postulatima, da se narodnjački ,jugoslavizam“ ne može označiti kao „ideologija“, ali da je bio element njihove cjelovite hrvatske nacionalne integracijske ideologije. A to znači da je u postojećim povijesnim pri-

\footnotetext{
$\overline{40}$ Diana STOLAC, Nazivi hrvatskoga jezika,.n.dj. 116.

41 Usp. AUBURGER, Grundzüge der Kulturpolitik von Josip Juraj Strossmayer, passim.

42 Kosta MILUTINOVIĆ, Štrosmajer i jugoslovensko pitanje, Novi Sad: Institut za izučavanje istorije Vojvodine, 1976., 50.

43 GROSS, SZABO, Prema hrvatskome građanskom društvu, usp. poglavlje „Društvene i nacionalnointegracijske ideologije“,157-170.
} 
likama jugoslavenska ideja bila proizvod hrvatske sredine, element ideologije proizišle iz socijalnog mentaliteta hrvatske tradicionalne društvene elite koja je bila $\mathrm{u}$ procesu integriranja $\mathrm{u}$ naciju. Na putu definiranja svojega nacionalnog identiteta ona je za sebe prihvaćala višestruki, slojeviti identitet - hrvatski etnički i politički te slavenski i južnoslavenski - pri čemu su te razine identiteta međusobno interferirale, a Karadžićeva reforma srpskoga književnog jezika pojačala je poimanje o jedinstvenom hrvatskom i srpskom književnom jeziku te etničkoj bliskosti.

Prema drugačijem modelu nastala je ideologija Stranke prava koja je u svoje središte stavila hrvatski nacionalni identitet i koja je, nakon dva desetljeća prevlasti ideologije Strossmayera i Narodne stranke, s drugačijim društvenim nositeljima preuzela vodstvo u političkom životu u Hrvatskoj.

4.

Strossmayer je ulogu Hrvatske, osim u traženju rješenja za njezin politički položaj u Srednjoj Europi, vidio i u rješavanju istočnog pitanja - o čemu niže u ovom poglavlju. Napose je ulogu Hrvatske vidio u oslobađanju Bosne, pri čemu je na zapadnu Bosnu (,tursku Hrvatsku“) gledao kao na dio hrvatskoga povijesnog teritorija. Vjerovao je da Habsburška Monarhija ima povijesnu misiju potiskivanja Osmanskoga Carstva s Balkanskog poluotoka, ali da to ne može činiti kao centralistički ili dualistički uređena država, tj. bilo u njemačkom ili zajedničkom njemačkom i mađarskom interesu. Smatrao je da se Monarhija mora u vlastitom interesu federalizirati kako bi u njoj ojačao utjecaj slavenskog elementa i napose položaj Hrvatske. U sklopu te koncepcije bila je (kao i 1848. godine) prisutna i ideja o povezivanju u federativno povezanu zajednicu južnoslavenskih zemalja Monarhije - Hrvatske, slovenskih zemalja i Vojvodine. Samostalna Hrvatska, smatrao je Strossmayer, otvorila bi put Habsburškoj Monarhiji u rješavanju istočnog pitanja jer bi trebala preko Hrvatske preuzeti ulogu u potiskivanja Osmanskoga Carstva, prije svega u oslobođenju Bosne, koja bi ušla u sastav Hrvatske. Smatrao je da Hrvatska i zbog svoje kulturne razvijenosti (i sam je poticao izgradnju njezinih kulturnih i znanstvenih institucija) ima misiju u potiskivanju retrogradnog osmanskog sustava, ali je bio spreman prepustiti vodeću ulogu u istočnom pitanju Srbiji ako Hrvatska ostane podčinjena bilo njemačkoj bilo mađarskoj prevlasti, odnosno ako bi potiskivanjem Osmanskoga Carstva bila na Balkanu uspostavljena njemačka ili mađarska hegemonija.

Takvo svoje kompleksno stajalište Strossmayer je iznio na početku 1860-ih godina, u vrijeme kada je Hrvatska bila podvrgnuta bečkom centralističkom 
režimu, u razgovoru s dvjema Engleskinjama koje su ga posjetile u Đakovu i koje su mu - kako je pisao Račkom - iznijele mišljenje "da su Srbi praeferenter pozvani osloboditi slavjanstvo tursko“. Svoju reakciju na to stajalište prepričao je u pismu Račkom: „Ja im rekoh da im (Srbima; N. S.) mi u tom poslu ne ćemo na putu biti. Bog im pomogao! Međutim doslje nisu još osobitu kakvu vještinu niti u promicanju kulturnih svrha, niti u borbi proti Turstvu pokazali. Mi smo žalibože Hrvati priječeni od one strane, koja bi u vlastitom svome interesu imala nas podupirati. ${ }^{\prime 44}$

Strossmayer je imao predodžbu o budućoj južnoslavenskoj državnoj zajednici, ali je njezin nastanak mogao zamisliti tek u dalekoj budućnosti i nikad takav program nije izričito formulirao. Planove o konkretnom ali dugoročnom djelovanju u skladu s takvim dalekim ciljem prihvaćalo je vodstvo Narodne stranke uz vjerojatnu Strossmayerovu suglasnost, ili su u njihovu krugu takvi programi formulirani, u kriznim situacijama u Habsburškoj Monarhiji i u samoj Hrvatskoj. Prvi put to je bilo nakon poraza Monarhije 1866. u ratu s Pruskom, kada je postojala mogućnost da Pruska priključenjem austrijskog dijela Monarhije stvori veliku Njemačku, te bi Hrvatska ostala u zajednici s Ugarskom, ili da se Beč kako bi stabilizirao unutrašnju situaciju - okrene nagodbi s Mađarima. U isto je doba u Srbiji obnovljena ideja o oblikovanju u Habsburškoj Monarhiji Dunavske konfederacije koja bi obuhvatila Čehe, Mađare i južnoslavenske narode i bila bi prijateljska prema Srbiji. U isto vrijeme tekla je u Srbiji na čelu s knezom Mihajlom Obrenovićem i ministrom Ilijom Garašaninom akcija na stvaranju saveza balkanskih država i oslobodilačkih pokreta s ciljem oslobađanja balkanskog prostora od osmanske vlasti i širenja Srbije na teritorije pod osmanskom vlasti, prije svega na Bosnu. Garašanin je Strossmayeru - koji je, kao apostolski administrator za katolike u Srbiji, bio u prijateljskim odnosima s knezom Mihajlom predložio (vjerojatno preko Andrije Torkvata Brlića) pokretanje takve zajedničke akcije u skladu s krajnjim ciljem osnivanja južnoslavenske države neovisne o Austriji i Turskoj, tj. države koja bi u skladu s tadašnjom politikom Srbije okupila južnoslavenske zemlje pod turskom vlasti. Strossmayer je pristao podržati Srbiju u takvom djelovanju, dapače - izrazio je spremnost da djelatnost kneza Mihajla javno podrži kao njegov ministar. ${ }^{45}$ Međutim težište svojega djelovanja stavio je na rješavanje položaja Hrvatske u Habsburškoj Monarhiji, za što su se u još uvijek nestabilnim prilikama u Monarhiji i Srednjoj Europi nudile različite

\footnotetext{
Strossmayer - Račkom, Đakovo, 7. listopada 1863., KORS I., 18.

45 Antonije Orešković - knezu Mihajlu Obrenoviću, Beograd, 25. kolovoza / 6. rujna 1866., kod: Vojislav V. VUČKOVIĆ, Politička akcija Srbije u južnoslovenskim pokrajinama Habsburške monarhije 1859-1874, Beograd: Naučno delo, 1965., 223-224; JAKŠIĆ, VUČKOVIĆ, Spoljna politika Srbije, 274.
} 
mogućnosti, pa i mogućnost federalizacije Habsburške Monarhije, što bi omogućilo i Hrvatskoj jače angažiranje u rješavanju istočnog pitanja. ${ }^{46}$

Strossmayer je drugačije postupio nakon što su kretanja u unutarnjoj politici Monarhije jasno krenula prema nagodbi i kada je Garašanin na proljeće 1867. godine ponudio Strossmayeru i vodstvu Narodne stranke ugovor o suradnji u radu na oslobođenju Bosne u sklopu dugoročnog djelovanja s ciljem stvaranja južnoslavenske države. Program koji je Garašanin 1867. ponudio Strossmayeru razlikuje se po svojoj koncepciji od njegova Načertanija, nacrta vanjske politike Srbije iz 1844. U Načertaniju je iznesen program stvaranja velike Srbije koja bi obuhvatila zemlje nekadašnjega Dušanova carstva, ${ }^{47}$ dok je u programu iz 1867. kao krajnji cilj zajedničke akcije proklamirano stvaranja jugoslavenske države. To je program prilagođen aktualnoj politici proširenja Srbije u sklopu suradnje s drugim balkanskim državama i oslobodilačkim pokretima i pridobivanju Narodne stranke na suradnju u djelovanju s ciljem oslobođenja Bosne od osmanske vlasti kao preduvjeta za - kada se za to stvore politički uvjeti - njezino priključenje Srbiji.

Tekst programa iz 1867. godine sastavio je Antonije Orešković, krajiški časnik koji je prešao u službu Srbije, a redigirao ga je Garašanin. Krajnji cilj predložene suradnje bio je - kao što je na početku programa navedeno - „oslobođanje hristijana pod jarmom turskim stenjajući, za stvoriti polje radi sajedinjenja sviju jugoslavenski plemena u jednu saveznu državu", tj. u konfederativno uređenu državu, premda je u sljedećoj rečenici zaključeno da će se unutarnje uređenje buduće države odrediti „po udjejstvovanom oslobođenju“. U radu na ostvarenju toga cilja surađivali bi „Beograd i Zagreb“, ali bi vodeću političku i vojnu akciju vodio Beograd, „u čemu će ga Zagreb podpomagati“. Stvarni cilj ugovora bio je osigurati pomoć Narodne stranke planiranom ustanku u Bosni i Hercegovini. Narodna stranka trebala bi organizirati odbore koji bi ustanak opskrbljivali materijalno i dobrovoljcima. Istodobno bi Narodna stranka, kako bi osigurala ulogu Hrvatske u potpomaganju ustanka, trebala „izbjegavati i savez s Ugarskom i Bečom" (tj. izboriti federalizaciju Monarhije), ili u odnosima s Ugarskom (tj. ako se ostvare kretanja prema dualizmu) izboriti za Hrvatsku položaj koji bi joj osigurao da se može „što slobodnije okretati kod svoje kuće“. Neposredni cilj čitave akcije bio bi ishoditi da europske sile nakon uspješnog ustanka prihvate autonomiju Bosne uz očuvanje integriteta Osmanskog Carstva. Naime, prema

\footnotetext{
$\overline{46}$ Grgur JAKŠIĆ, Vojislav J. VUČKOVIĆ, Spoljna politika Srbije za vlade kneza Mihaila (proi balkanski savez), Beograd: Istorijski institut, 1963., 267-275.

47 Tekst Načertanija Ilije Garašanina v. kod: Etničko čišćenje / Povijesni dokumenti o jednoj srpskoj ideologiji, Zagreb: Nakladni zavod Globus, 1993., 44-53.
} 
tekstu programa, načelo autonomije Bosne „valja zasad dok se [ne] osilimo svakako poštovati“, tj. dok se - što nije izričito navedeno - ne stvore uvjeti za njezino priključenje Srbiji. Oslobođenjem Bosne bi, konstatira se, „narodna stvar dobila u Turskoj prostran i čvrst temelj“ za „polet k obštoj konačnoj cjeli““ ${ }^{48}$ Strossmayer je predloženi program u dogovoru s vodstvom Narodne stranke prihvatio i njegov je pristanak Garašaninu prenio Matija Mrazović, koji je kod njega u Đakovu boravio u ožujku 1867. prije odlaska u Beograd. ${ }^{49}$

Strossmayer je u skladu sa svojom politikom, što je istodobno bilo u skladu s ugovorenim programom suradnje sa Srbijom, u vrijeme priprema za Austrougarsku nagodbu nastojao osigurati što samostalniji položaj Hrvatske u Monarhiji kako bi - među ostalim - mogla djelotvornije utjecati i na rješavanje istočnog pitanja, napose sudbine Bosne. Međutim, nakon već spomenutog sukoba s Franjom Josipom u travnju 1867., kada je u audijenciji odbio podržati kretanje prema dualizmu, otputovao je u Pariz. U Parizu - gdje je boravio od svibnja do početka kolovoza $1868 .^{50}$ - bio je u dodiru s poljskom emigracijom koja je težila obnovi cjelovitosti Poljske podijeljene između Rusije, Pruske i Habsburške Monarhije. Najveći dio povijesnog teritorija Poljske bio je u sastavu Ruskog Carstva, te $\mathrm{u}$ poljskoj politici u Habsburškoj Monarhiji i u poljskoj emigraciji nije bila prisutna slavenska ideja, a poljska politika u Habsburškoj Monarhiji podržavala je kretanja prema dualizmu. Strossmayer je, naprotiv, u memorandumu koji je uputio članu vodstva poljske emigracije Vladislavu Czartoryskom predlagao da se u Monarhiji uspostavi suradnja poljske i hrvatske politike na programu federalizacije Monarhije. ${ }^{51}$ Pojedini su povjesničari Strossmayerovo obraćanje Czartoryskom označili kao napuštanje programa dogovorenog sa Srbijom i to su istaknuli kao dokaz o Strossmayerovoj ekskluzivnoj, dapače „velikohrvatskoj“ politici. ${ }^{52} \mathrm{Ta}$ je Strossmayerova akcija, međutim, bila u skladu kako s njegovim

$\overline{48}$ Program jugoslovenske politike predložen od strane Garašaninove Štrosmajeru, [Beograd, ožujak 1868], kod: VUČKOVIĆ, n.dj. 273-281; v. također: Program južnoslavenske politike iz 1867. godine, kod: Petar KORUNIĆ, Jugoslavizam i federalizam u hrvatskom nacionalnom preporodu 1835-1875, Zagreb: Globus, 1989., 239-243; Program južnoslavenske politike / Tajni program suradnje hrvatske Narodne stranke i vlade Kneževine Srbije (s. 1.,, 1867.), kod: CIPEK, MATKOVIĆ, Programatski dokumenti, n.dj.178-182

49 Strosmayer - Račkom, Đakovo, 21. 0žujka 1868., KORS I, 399.

50 Usp. Strossmayerova pisma Račkom iz Pariza 24. svibnja i 1. srpnja, te iz Đakova 24. kolovoza 1868. KORS I., 45-47; JAKŠIĆ, VUČKOVIĆ, Spoljna politika Srbije, n.dj. 356-363.

51 Piotr ŽUREK, Strossmayer i Poljaci, u: Josip Juraj Strossmayer / Hrvatska. Ekumenizam. Europa / Chorwacja. Ekumenizm. Europa,n.dj. 309-322.

52 Vasilije KRESTIĆ, Biskup Štrosmajer: Hrvat, velikohrvat, Jugoslaven, Jagodina: Gambit, 2006., 39. Isti autor u predgovoru knjige tvrdi da Strossmayer "uopšte nije bio Jugosloven, već Hrvat i to velikohrvat" (str 13). 
spomenutim općenitim stajalištem, tako i s ugovorom sa Srbijom o potrebi jačanja samostalnog položaja Hrvatske u Monarhiji radi jačanja njezine uloge i u rješavanju istočnog pitanja, napose sudbine Bosne.

Međutim knez Mihajlo Obrenović odustao je od planiranih akcija u suradnji s balkanskim državama i oslobodilačkim pokretima s ciljem oslobađanja teritorija pod osmanskom vlasti nakon što mu je mađarski ministar predsjednik Gyula Andrássy na sastanku u Ivanjki na ljeto 1867. ponudio podršku u diplomatskoj akciji s ciljem priključenja istočne Bosne Srbiji bez rata. ${ }^{53}$ Krajem 1867. Mihajlo je zbog osobnih sukoba također otpustio Garašanina. Matija Mrazović je na početku 1868. od Antonija Oreškovića, preko kojega je održavao vezu s vladom Srbije, saznao da je srbijanska vlada odustala od ",ugovorena programa“, tj. rada na oslobođenju Bosne i suradnje s Narodnom strankom, te je o tome obavijestio Strossmayera. Mrazović je postupak srpske vlade ocijenio kao dokaz da se srpska vlada odriče vodeće uloge u akciji koja „smjera na oslobođenje braće ispod turskoga jarma te ima osnovati jezgru za ujedinjenje jugoslavenstva u jednu državu“. To je ocijenio kao „izdaju zajedničkog programa“ i zaključio da nakon toga Narodna stranka ubuduće u takvu akciju može krenuti samo „pomoćju države u kojoj sada živimo “. ${ }^{54}$

Tako je prekinuta akcija s ciljem oslobođenja Bosne koju je Strossmayer podržavao, ali je misao o zajedničkoj državi južnoslavenskih naroda negdje u dalekoj budućnosti bila stalno prisutna u ideologiji Narodne stranke, te je formulirana $\mathrm{u}$ tajnim programima $\mathrm{u}$ trenutcima razočarenja $\mathrm{u}$ rezultate konkretne politike, kada su nastojanja za postizanjem samostalnog položaja Hrvatske u Habsburškoj Monarhiji doživljavala poraz. Uvođenje dualizma i nametnuta Hrvatsko-ugarska nagodba 1868. te nakon toga učvršćenje dualizma i revizija Nagodbe 1873. u sklopu promjena odnosa u Srednjoj Europi te priklanjanje srpske politike dualizmu doveli su do dilema u Narodnoj stranci o pravcu buduće politike. Na te je dileme i polarizaciju u redovima Narodne stranke u sjevernoj Hrvatskoj i Dalmaciji nastojao odgovoriti najprije - nakon sklapanja Hrvatsko-ugarske nagodbe - Mihovil Pavlinović, jedan od vođa Narodne stranke u Dalmaciji, a zatim - nakon revizije Nagodbe - krug oko Strossmayera. Oba su programa, uz samostalnost i cjelokupnost Hrvatske u Habsburškoj Monarhiji, predviđala u dalekoj budućnosti stvaranje južnoslavenske države (,Jugoslavije“) i ta dva cilja bili su konstanta u politici narodnjaka i Strossmayera u drugoj polovici 19. stoljeća.

JAKŠIĆ, VUČKOVIĆ, Spoljna politika Srbije, n.dj. 396-403.

54 Matija Mrazović - Josipu Jurju Strossmayeru, 22. veljače 1868., kod: Jaroslav ŠIDAK, Dva priloga hrvatskoj povijesti od 1868 - 1871., Historijski zbornik 19-20, 1966-67., 353-360. Pismo sadrži prijepise pisma Antonija Oreškovića Matiji Mrazoviću i Mazovićeva odgovora Oreškoviću u kojemu se nalaze citirana mjesta. 
Pavlinović, najistaknutiji zastupnik hrvatske nacionalne i državne ideje među narodnjacima s obje strane Velebita, sastavio je 1869. godine tajni program pod naslovom Hrvatska misao i u njemu iznio smjernice kojih bi se trebala pridržavati skupina vodećih narodnjaka iz sjeverne Hrvatske i Dalmacije u usmjeravanju hrvatske politike. ${ }^{55} \mathrm{U}$ programu je osuđivao velikosrpsku politiku i negiranje hrvatske nacionalne pripadnosti štokavaca katolika te odbacivao shvaćanje da jedino Srbija ima pravo na Bosnu. Srbiju je upućivao na širenje na srpske povijesne zemlje pod osmanskom vlasti, smatrao je da Hrvatska ima povijesno pravo na zapadnu Bosnu („Tursku Hrvatsku“), da Hrvatska i Srbija imaju podjednako pravo na istočnu Bosnu, ali je prihvaćao i mogućnost da, ovisno o političkim prilikama, čitava Bosna pripadne bilo Hrvatskoj bilo Srbiji. Krajnji cilj vidio je u stvaranju konfederativno uređenog "Jugoslavenskog saveza“, a njegovu političku svrhu (zajedničku obranu od pretenzija susjednih država) i uređenje (konfederativno) formulirao je riječima:

„Jugoslavenski će savez s jedne učuvati najsvetije osebnosti Slovencu, Hrvatu, Srbu, Bugaru, a s’ druge će zajamčiti zajedničku nezavisnost od vanjskog premoćja. Svi ti narodi imadu različitih domaćih interesa, ali su svim jednaki interesi na Dunavu i na Jadranskom moru. Jugoslavija će biti krasna i velika, ali ne poput jedinstvene Francuske, nit poput Italije, ni poput Njemačke, nego poput savezne Švajcarske, jali poput sjedinjenih Amerika. Bolje rekuć, Jugoslavija će biti kako najbolje Jugoslaviji dolikuje da bude: zajednica bratinskih naroda, savez država nerazdruživih družica. ${ }^{456}$

Pavlinović je svoj program poslao i Strossmayeru..$^{57}$ Učinio je to preko prijatelja Koste Vojnovića koji je program poslao Matiji Mrazoviću s molbom da ga (zajedno s Pavlinovićevim pismom) proslijedi Strossmayeru u Đakovo. ${ }^{58}$ Strossmayer je program i Pavlinovićevo pismo dobio dok je kod njega boravio Rački, te su ga zajedno pročitali i program načelno prihvatili, ali je Rački sma-

$\overline{55}$ Nikša STANČIĆ, Hrvatska nacionalna ideologija preporodnog pokreta u Dalmaciji / Mihovil Pavlinović $i$ njegov krug do 1869.,Zagreb: Sveučilište u Zagrebu, Centar za povijesne znanosti, Odjel za hrvatsku povijest, 1980., 329-339.

56 Mihovil PAVLINOVIĆ, Hrvatska misao (Program), kod: STANČIĆ, Hrvatska nacionalna ideologija, n. dj. 340-355; također kod: Mihovil PAVLINOVIĆ, Izabrani politički spisi, (prir. Nikša STANČIĆ), Zagreb: Golden Marketing, Narodne novine, 2000., 128-148. ; CIPEK, MATKOVIĆ, Programatski dokumenti, n. dj. 196-207.

57 Mihovil Pavlinović - Josipu Jurju Strossmayeru, Podgora, 31. kolovoza 1867., kod: Seid M. TRALJIĆ, Pisma Mihovila Pavlinovića F. Račkom i J. J. Strossmayeru šezdesetih godina XIX stoljeća, Radovi Instituta JAZU u Zadru, X., 1963., 412-413.

58 Kosta Vojnović - Matiji Mrazoviću, Split, 16. rujna 1869., kod: Petar KORUNIĆ, Prilog poznavanju političkog programa Narodne stranke u Dalmaciji 1869-1870. godine, Historijski zbornik XL (1), 1987.,253. 
trao da je u tom trenutku - kada su se u sjevernoj Hrvatskoj nakon nametnute Hrvatsko-ugarske nagodbe spremali izbori za Sabor i kada je u Dalmaciji bila izgledna pobjeda Narodne stranke na skorim saborskim izborima - važnije osigurati složan nastup narodnjaka u sjevernoj Hrvatskoj i Dalmaciji. ${ }^{59}$ Pavlinović je sadržaj svoga programa sažeo u krilatici Hrvat i katolik!, a njegovi javni nastupi u skladu s njom izazivali su podjele u Narodnoj stranci u Dalmaciji. Zbog toga je Strossmayer ocijenio da je njegov program ",pogibeljan slogi“. ${ }^{60}$

Nakon revizije Nagodbe, i time sloma Strossmayerove politike ostvarenja samostalnosti Hrvatske u Habsburškoj Monarhiji, nastao je 1874. godine program dugoročne politike Narodne stranke u sjevernoj Hrvatskoj s krajnjim ciljem stvaranja zajedničke države južnoslavenskih naroda. Program je nastao u najužem krugu vodstva stranke uz sudjelovanje (prema stajalištima u historiografiji) Strossmayera, Račkog i Matije Mrazovića. ${ }^{61}$ U njemu je kao konkretan politički zadatak naveden rad na ostvarenju teritorijalnog jedinstva hrvatskih zemalja, ali je predviđeno i da se u "političku zajednicu“ postupno okupe, s jedne strane, oko Hrvatske svi južnoslavenski teritoriji u Habsburškoj Monarhiji (Vojvodina, ujedinjene slovenske zemlje), a da se, s druge strane, oko Srbije i Crne Gore okupi što više južnoslavenskih zemalja u Osmanskom Carstvu. Kao primarni cilj naznačeno je oslobođenje Bosne. ${ }^{62}$ Krajnji cilj te politike formuliran je već u prvoj točki programa:

„Najskrajniji cilj zajedničkih težnja i zajedničkog rada narodnoga u Srba, Hrvata, Slovenaca i Bugara, da bude njihovo ujedinjenje u nezavisnu i slobodnu, narodnu i državnu zajednicu Jugoslavensku." Odluka o unutarnjem uređenju zajedničke države ostavljena je budućnosti, ali su predviđena glavna načela prema kojima bi ona bila organizirana kao konfederacija. Naime, točka V. glasi: „U medjusobnijem odnošajima, da državna samostalnost i samoupravna prava pojedinijeh Jugoslavenskijeh zemaljâ, imaju ostati sasvijem nepovredjena i u podpuno slobodnoj volji onog dijela naroda, koji tu samostalnost i ta prava uživa.. ${ }^{163}$

59 Franjo Rački - Matiji Mrazoviću, Đakovo, 22. rujna 1869., kod: KORUNIĆ, Prilog poznavanju, 255257.

Kosta Vojnović je u pismu Pavlinoviću prenio podatke o razgovoru brata Luje Vojnovića sa Strossmayerom u Beču, v. Kosta Vojnović - Mihovilu Pavlinoviću, Split, 20. siječnja 1870., kod: Korespondencija Mihovila Pavlinovića (prir. Ante PALAVRŠIĆ, Benedikta ZELIĆ) , Split: Historijski arhiv Split, 1962., 132.

61 MILUTINOVIĆ, Štrosmajer i jugoslovensko pitanje, 94-95; KORUNIĆ, Jugoslavizam i fedralizam, 245.

62 Jugoslavenski program Narodne stranke (Zagreb, 1874.), kod: CIPEK, MATKOVIĆ, Programatski dokumenti, 260-261. Spis se nalazi u ostavštini Slavoljuba Vrbančića u Nacionalnoj i sveučilišnoj knjižnici u Zagrebu. 
Strossmayer je na samom početku ustanka u Bosni i Hercegovini 1875. godine pokušao Hrvatsku učiniti akterom u rješavanju sudbine Bosne, čime su se zaokupljala oba spomenuta programa proistekla iz redova Narodne stranke. Kao što je na početku ustanka pisao Račkom, smatrao je da bi „za Hrvatsku i sramotno i štetno bilo, ako se ne bi u ovomu metežu, koji se rađa, za staru svoju postojbinu ozbiljno pobrinula“. Raspolagao je podatcima da se u dinastičkim krugovima u Beču razmišlja o Hrvatskoj kao osloncu dinastije i o jačanju njezina položaja, a smatrao je da je „u interesu dinastije, da se Hrvatsku podupire“. Zbog toga je molio Račkog da razgovara s banom Mažuranićem i predloži mu da razgovara s carem o angažmanu Hrvatske u vezi s ustankom u Bosni. ${ }^{64}$ Mažuranić je doista razgovarao s Franjom Josipom, ali je on odbio izravno uključivanje Monarhije u bosanska kretanja opravdavajući to međunarodnim obvezama. ${ }^{65}$ Pri tome je mislio na dogovor postignut na sastanku njemačkog, austrijskog i ruskog cara 1872. u Berlinu („trocarski savez“) o očuvanju integriteta Osmanskog Carstva, ali i na svoje kasnije dogovore s ruskim carem kojima je međusobno priznato pravo na širenje na Balkanu, tj. širenje Austro-Ugarske na Bosnu.

Zbog toga se u novim uvjetima Strossmayer okrenuo alternativnom rješenju i pozdravio pokušaj Srbije i Crne Gore 1876. da vojno posjednu i podijele teritorij Bosne i Hercegovine. No, srpska je vojska u Bosni doživjela poraz, a postalo je također izgledno da će europske sile bitno utjecati na razrješenje sudbine Bosne i Hercegovine. Zbog toga je Strossmayer stupio u dodir s britanskim političarom Williamom Gladstoneom i nastojao preko njega utjecati na dogovore velikih sila. U dopisivanju s Gladstoneom u razdoblju 1876. - 1878. godine istaknuo je Hrvate kao „toskanski element" koji zbog kulturnih institucija koje su u zadnje vrijeme izgradili imaju zadatak voditi južne Slavene na putu kulturnog napretka. Nasuprot tome istaknuo je Srbiju koja ima iskustvo polustoljetne samostalnosti i predložio da Bosna dobije autonomiju u sklopu Osmanskog Carstva i da se stavi pod zaštitu Srbije. ${ }^{66}$ Nije, dakle, zahtijevao sjedinjenje Bosne sa Srbijom, ali je otišao korak dalje od programa iz 1867. godine koji je inzistirao na striktnom pridržavanju načela autonomije Bosne.

Nakon poraza Srbije u ratu u Bosni najveći dio hrvatske politike, narodnjaci i pravaši (osim samih vođa, Strossmayera i Starčevića), zagovarao je priključenje Bosne i Hercegovine Hrvatskoj, što je dovelo do sukoba srpske i hrvatske politike. Berlinski kongres europskih sila iz 1878. godine dao je Bosi i Hercegovini autonomiju, ali je upravu povjerio Austro-Ugarskoj.

\footnotetext{
64 Strossmayer - Račkom, Đakovo, 22. kolovoza 1875., KORS I, 372.

65

Rački - Strossmayeru, Zagreb, 27. kolovoza 1875., KORS I, 374

66

MILUTINOVIĆ, Štrosmajer i jugoslovensko pitanje, 217-229 (poglavlje „Štrosmajer i Gledston“).
} 
A zbivanja u Habsburškoj Monarhiji te srednjoj i jugoistočnoj Europi nakon Berlinskoga kongresa otvorila su dugoročnu situaciju u kojoj je bila potpuno blokirana mogućnost za ikakve promjene položaja Hrvatske. Njemačka je pod vodstvom kancelara Bismarcka odustala od programa stvaranja velike Njemačke priključenjem austrijskog dijela Habsburške Monarhije i podržala dualizam u kojemu su austrijski Nijemci dijelili vlast s Mađarima, vodila je politiku ravnoteže sila u srednjoj Europi i u istočnom pitanju na Balkanu, koji je postao prostor njemačkoga političkog i gospodarskog prodora na Istok (Drang nach Osten), čime je bio blokiran proces oslobađanja preostalih teritorija pod osmanskom vlasti. Srbija je tajnim ugovorom stupila u savez s Habsburškom Monarhijom, kojoj je prepustila usmjeravanje svoje vanjske politike i odustala od projekta priključenja Bosne, te je neuspjelim ratom 1885. pokušala osvojiti dio teritorija Bugarske, što je Strossmayer najoštrije osudio (o čemu niže).

U Hrvatskoj je uveden represivni režim bana Khuen-Héderváryja, a podržavala ga je Narodna stranka, koja je prihvatila oportunističku politiku i postala režimska stranka, dok je Strossmayer podržao osnivanje male oporbene Neodvisne narodne stranke. Strossmayer je bio svjestan da je dualizam dugoročno rješenje i da je time onemogućena uloga Hrvatske kao čimbenika u rješavanju istočnog pitanja i priključenje Bosne Hrvatskoj. Smatrao je da u takvim prilikama vodeću ulogu u rješavanju istočnog pitanja treba preuzeti Srbija. „Mi smo Hrvati četrdeset godina trsili se Hrvatom prvenstvo na Balkanskom poluotoku osigurati“, pisao je 1889. godine. „Oni koji bi to u vlastitom interesu imali poduprijeti, odbili su nas, odbacili su nas, osumnjičili su nas itd. Sad je prvenstvo to u srpskih ruku, i pravo je tako. ${ }^{167}$ Ali je i dalje bio uvjeren da je u interesu Monarhije i njezinih slavenskih naroda njezina federalizacija te oslonac na $\mathrm{Hr}-$ vatsku u istočnom pitanju. Tako je 1891. pisao: „Da je u Beču samo iole razbora i pravde, Česi bi bili jaki zid i neporušivi bedem poplavi nemeckoj. [...] Mi u Austro-Ugarskoj prvo mjesto za Česima kano Slovjeni zauzimamo. Što su Česi na sjeveru, to smo mi na jugu. Da je samo trunke razbora i pameti, mi bi jedini bili faktor, koji monarhiji na jugoistok put krči. ${ }^{168}$ Dapače, nikad nije izgubio nadu u promjene koje će omogućiti da Hrvatska postane samostalni čimbenik u Habsburškoj Monarhiji i u rješavanju istočnog pitanja. Tu je nadu iskazao 1894. u vezi sa zahtjevom sarajevskog Zemaljskog muzeja da Akademija vrati slike fojničkog samostana koje je samostan predao njemu, a on ih je predao Akademiji. U pismu gvardijanu fojničkog samostana fra Ivanu Vujičiću Strossmayer je 1892. godine napisao da će slike vratiti „,kad Bosna bude posve neodvisna“" „,Kad

67 Strossmayer - Račkom, Đakovo, 7. travnja 1889., KORS IV., 73.

Strossmayer - Račkom, Đakovo, 24. rujna 1991., KORS IV., 280-281. 
jedamput bude izbiljam Bosna posve svoja, ili što je isto, kad se bude s nama u jedno tijelo spojila. ${ }^{.69}$

To je također razdoblje žestokih sukoba hrvatskih oporbenih stranaka i srpske politike, koja je podržavala dualizam i režim bana Khuen-Héderváryja i bila dio sustava koji je Hrvatsku držao u pokornosti dualizmu i mađarskoj prevlasti te koja je katolike štokavce proglašavala Srbima. U takvoj situaciji Strossmayer je ustrajao uz ideju o Hrvatima i Srbima kao „braći“ u etničkom pogledu, ali je istodobno i osuđivao aktualnu srpsku politiku. U vrijeme sukoba hrvatske i srpske politike u korespondenciji s Račkim u više je navrata 1880-ih godina na svoj vehementni način reagirao na iskaze velikosrpske politike. Godine 1883. pisao je Račkom: „Srbi nemaju na svijetu većih prijatelja od nas dvojice“ i podsjećao na svoje zalaganje kod Gladstonea da poslije ustanka u Bosni i Hercegovini Srbi „ne ostanu praznih rukava“. ${ }^{70}$ A 1884. godine pisao je Račkom ovo: „Srbi su nam krvavi neprijatelji. [...] Dočim se mi ljuto borimo prot Madžara, Srbin brat iza leđa na nas navaljuje. ${ }^{.71}$ Napose je žestoko osudio rat Srbije protiv Bugarske povezavši to s protuhrvatskom politikom Srbije. „Ludi su Srbi - pisao je1885. god. - mislili, kad sataru pomoću vječitih neprijatelja Slavjanstva državnu ideju hrvatsku, pod kojom bratsku zaštitu nađoše, kroz stoljeća je uživahu, i kad satru dobri bugarski narod - eto im gotovo Dušanovo carstvo! Uopće ta ideja uskrsnuća Dušanovoga carstva luda je ideja i puka opsjena." Ideji velike Srbije suprotstavio je "misao slavjanske federacije na Balkanskom poluotoku“"72 Istodobno s osudom velikosrpske politike Strossmayer je zazivao ostvarivanje južnoslavenske kulturne suradnje. U vezi s obavijesti koju je iste, 1885. godine dobio od Račkoga da se u Beogradu priprema kongres južnoslavenskih književnika i znanstvenika, Strossmayer je otpisao: „Treba iz svih sila na tome raditi, da se barem u kulturnoj sferi ljubav, sloga i sporazumljenje potpuno postigne. ${ }^{4 / 73}$

\footnotetext{
$\overline{69}$ Strossmayer - fra Ivanu Vujičiću, Đakovo, 7. veljače 1892., KORS IV., 306.

70 Strossmayer - Račkom, Đakovo, 18. ožujka 1883., KORS III., 59.

71 Strossmayer - Račkom, Đakovo, 10. travnja 1884, kod: KORS III. 118-119. Neki su autori ovu i slične Strossmayerove izjave tumačili kao njegovo odustajanje od jugoslavenske ideje (v. Predgovor D. Jelčića u knjizi STROSSMAYER, Izabrani književni i politički spisi, n. dj., 22-24). ili da je napustio ideju o jugoslavenskoj državi i okrenuo se rješenju položaja Hrvatske u sklopu federalizacije Habsburške monarhije (Ankica PEČARIĆ, Josip PEČARIĆ, Strossmayerova oporuka, Zagreb: HAZU, 2002., 53).

72 Strossmayer -Račkom, Đakovo, 29. studenog 1885., KORS III., 199.

73

Strossmayer - Račkom, Đakovo, 10. svibnja 18885., KORS III, 174.
} 
5.

Ovaj tekst završava izvodom iz Strossmayerova pisma Račkom od 19. ožujka 1879. u vezi s pripremama za pokretanje oporbenog glasila. Pismo je nastalo pred kraj Mažuranićeva banovanja, kad je nakon revizije Nagodbe Narodna stranka prešla u vode oportunizma, a Strossmayer se povukao iz javne politike i kada je nakon okupacije Bosne i Hercegovine došlo do sukoba hrvatske i srpske politike, a započeo je i uspon Stranke prava. U pismu je Strossmayer iznio stajališta koja pokazuju svu kompleksnost njegove politike. Račkom je pisao:

„Nitko nije veći prijatelj Hrvata nego ja. Ali žalibože mogu reći, da je Hrvatska neizmjerno duboko pala u mojih očiju. Valja dakle Hrvatstvo gojiti, valja i ondje, gdje bi Srpstvo nesvijesnim načinom htjelo potkopati općeniti temelj, na komu se danas braniti moramo i možemo. Valja ga suzbijati, ali valja pomisliti, da je $\mathrm{Hr}$ vatstvo i Srpstvo samo sredstvo, posljednji pako cilj da je jedinstvo narodno. Valja znati, da su nami ruke vezane, i kad će se razvezati, to samo Bog zna. [...] Ali, ako bez vanjskih događanja jedva ćemo do one snage doprijeti, koju bi imati morali, da svrhu svoju postignemo, onda nam je pomislit, da su na Jugu dva srpska plemena posve prosta, od kojih jedan (Crna Gora; N.S.) barem plemenite je naravi i nakane. [...] Ovo se sve može složiti s najskrupuloznijom lojalnosti.“74

Taj Strossmayerov tekst sadrži sve bitne elemente njegove nacionalne ideologije i načela političkog djelovanja. To je shvaćanje o hrvatskoj etničkoj i političkoj individualnosti, shvaćanje o ,jedinstvu narodnom“ Hrvata i Srba u sklopu južnoslavenske cjeline, osuda velikosrpske politike, program političke samostalnosti Hrvatske u sklopu Habsburške Monarhije i djelovanja Hrvatske u rješavanju istočnog pitanja, shvaćanje o Srbiji i Crnoj Gori kao samostalnim čimbenicima u rješavanju istočnog pitanja i oslobađanju južnoslavenskih prostora pod Osmanskim Carstvom te o djelovanju Hrvatske u Habsburškoj Monarhiji i u rješavanju istočnog pitanja uz punu lojalnost prema Habsburškoj Monarhiji. Strossmayer je vjerojatno vjerovao da će u budućnosti nastati južnoslavenska država. Međutim, nije sačuvan nijedan dokument u kojem bi on sam izričito iznio takvo shvaćanje. Programatski spis iz 1874. koji sadrži izričitu ideju o stvaranju konfederativno uređene južnoslavenske države nastao je u Strossmayerovu krugu, ali nema dokumentirane potvrde za tvrdnje $u$ historiografiji da je sam Strossmayer sudjelovao u njegovu oblikovanju. No, ne može se osporiti ni da je Strossmayer s njegovim sadržajem bio upoznat. Nepostojanje dokumenta s takvim sadržajem koji bi potekao iz Strossmayerova pera može se objasniti Strossmayerovim oprezom, činjenicom da je dobro znao da je pod policijskom prismotrom i da bi otkrivanje takvog dokumenta bilo povod za "prisilne mjere“ (Zwangsmassregeln) kakvima mu je već 1867. godine Kaiser und König Franz Josef I. zaprijetio.

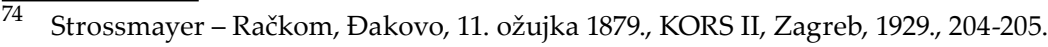




\section{Summary}

\section{Josip Juraj Strossmayer in Croatian Politics - Politics and National Ideology}

Bishop Josip Juraj Strossmayer was the leading personality of the National Party and the most distinguished person in the political life of Croatia in the second half of the 19th century. He belonged to the traditional elite, the leading social layer in the polarised society of the Northern Croatia, and the holder of this social layer's ideology. Elements of his national ideology were ethnic and political Croatism, and the idea of Slavism and South Slavism. The objectives of his political activity were the restoration of the territorial integrity (unification of Dalmatia with Northern Croatia), and the autonomy of Croatia within the Habsburg Monarchy. Strossmayer saw the solution of Croatia's position - depending on the change of relations in Central Europe and the Habsburg Monarchy - either in the federalisation of the Monarchy or, in the dual system, in the restoration of links between Croatia and Hungary as two political territories with equal rights. This policy had suffered defeat by the conclusion of Austro-Hungarian Compromise in 1867, and of the unfavourable Croatian-Hungarian Agreement in 1868, followed by the revision of the Agreement in 1873, pursuant to which Croatia's position was not changed for the better. After the defeat of his policy, Strossmayer withdrew from public political life, but continued to operate behind the scenes.

Strossmayer's idea of Slavism was connected with his ecumenism - the idea of getting Catholic and Orthodox Slavic nations closer. His idea of South Slavism rested on the (incorrect) notion of Croatian and Serbian being one and the same literary language. This notion further generated the idea of the ethnic kinship of the Croats and the Serbs with South-Slavic nations, and the idea of establishing a confederate state of all South-Slavic nations in distant future. This idea was formulated in a secret programme composed in 1874 in the circle around Strossmayer and the leadership of the National Party. Strossmayer believed that the mission of the Habsburg Monarchy was to liberate the South Slavs in the Balkans from the Ottoman Empire and to do so via Croatia due to its historical right to Bosnia, yet he sensed that the centralistic / dual Monarchy would restore German and Hungarian hegemony in the Balkans. He was therefore in 1867 prepared to support Serbia's plans for securing autonomy for Bosnia within the long-term plan for joining with Serbia and the establishment of a South-Slavic state in the Balkans. In 1875, when the uprising in Bosnia and Herzegovina began, Strossmayer endeavoured to persuade Emperor Franz Josef for the Habsburg Monarchy to intervene in Bosnia via Croatia, but failed. He hence decided to support Serbia in its efforts (made in vain) to take possession of Bosnia by fighting a war against Turkey. Later, he intervened with European powers to accept the autonomy of Bosnia and Herzegovina under the patronage of Serbia; however, the Berlin Congress of 1878 entitled the Habsburg Monarchy to occupy Bosnia and Herzegovina. In the time of the conflict between Croatian and Serbian policies, which arose from the issue of whom did Bosnia and Herzegovina belong to, Strossmayer strongly disapproved of radical appearances by Croatian and Serbian politici- 
ans. He believed that in future, political relations in Europe and the Habsburg Monarchy would change and hence Croatia's position in the Monarchy would change too, which would be a prerequisite for joining Bosnia and Herzegovina with Croatia.

Keywords: Josip Juraj Strossmayer; Croatia; Habsburg Monarchy; national ideology; Croats; Serbs; South Slavs; literary language; Eastern issue; Ottoman Empire; Serbia; Bosnia. 